\title{
Environmental Enrichment Rescues Postnatal Neurogenesis Defect in the Male and Female Ts65Dn Mouse Model of Down Syndrome
}

\author{
Lina Chakrabarti ${ }^{a}$ Joseph Scafidia,b Vittorio Gallo ${ }^{a}$ Tarik F. Haydar ${ }^{a, c}$ \\ ${ }^{a}$ Center for Neuroscience Research and b Department of Neurology, Children's National Medical Center, \\ Washington, D.C., and ' Department of Anatomy and Neurobiology, Boston University School of Medicine, \\ Boston, Mass., USA
}

\section{Key Words}

Down syndrome $\cdot$ Environmental enrichment .

Hippocampus · Neurogenesis · Gliogenesis · Cell

proliferation $\cdot$ Subventricular zone

\begin{abstract}
Down syndrome (DS), the most frequent genetic cause of intellectual disability and developmental delay, results from impaired neural stem cell proliferation and differentiation. Impaired neurogenesis in the neocortex, hippocampus and cerebellum is believed to be the underlying cause of learning and behavioral deficits in the Ts65Dn mouse model of DS. Aggressive sensorimotor and cognitive therapies have shown promise in mitigating the cognitive disabilities in DS but these behavioral therapies have not yet been investigated at the cellular level. Here, using the Ts65Dn mouse model of DS, we demonstrate that a combination of environmental enrichment and physical exercise starting in juvenile mice (postnatal day 18) markedly increases cell proliferation, neurogenesis and gliogenesis in the hippocampal dentate gyrus (DG) and the forebrain subventricular zone (SVZ) of both male and female mice. Enrichment and exercise increased the rate of Ts65Dn DG neurogenesis to be comparable to
\end{abstract}

that of the nonenriched euploid group, while the effect on SVZ neurogenesis was reduced and seen only after prolonged exposure. These results clearly indicate that in a comprehensive stimulatory environment, the postnatal DS brain has the intrinsic capability of improving neurogenesis and gliogenesis to the levels of normal matched controls and that this cellular response underlies the cognitive improvement seen following behavioral therapies.

Copyright $\odot 2011$ S. Karger AG, Basel

\section{Introduction}

Down syndrome (DS), caused by the triplication of human chromosome 21, occurs in 1 of 732 live births and is therefore the most frequent genetic cause of mental retardation. Although the etiology of the cognitive deficits is not well understood, both prenatal and postnatal abnormalities have been found in the DS central nervous system. Studies on the DS brain indicate that defects beginning prenatally in the DS brain persist after birth and that most of the neuropathological changes may be due to changes in neural stem and precursor cell proliferation $[1,2]$. This stem cell defect impacts on DS brain growth

\section{KARGER}

(๑) 2011 S. Karger AG, Basel

Fax +4161306 1234

E-Mail karger@karger.ch

www.karger.com
Accessible online at: www.karger.com/dne
Tarik F. Haydar, $\mathrm{PhD}$

Department of Anatomy and Neurobiology, Boston University School of Medicine 72 East Concord Street, L-816C

Boston, MA 02118 (USA)

Tel. +1 617638 4249, E-Mail thaydar@bu.edu 
and function which results in significant delays in reaching developmental milestones, intellectual disability and sensorimotor deficits.

Investigation of central nervous system abnormalities and cognitive dysfunction in DS has been greatly facilitated by the development of the Ts65Dn mouse model, which is segmentally trisomic for 136 of the 384 genes present on human chromosome $21[3,4]$. Ts65Dn mice have many neurologic similarities to human DS including defects in cell proliferation and neurogenesis in the hippocampus and cerebellum [5-7] as well as learning and memory deficits [8-10]. Importantly, recent studies demonstrated a decreased neural stem cell proliferation rate and reduced neurogenesis during Ts65Dn forebrain development [11]. These defects alter the tempo of synapse formation and synaptic plasticity in Ts65Dn brain [12-15], and are thought to be the basis for the cognitive deficits in this mouse. Therefore, it is likely that restoration of proper levels of neurogenesis would improve cognitive ability in Ts65Dn mice as well as DS individuals. In fact, chronic treatments with antidepressants like fluoxetine and lithium have been shown to increase neurogenesis in the postnatal germinal zones of Ts65Dn mice [16, 17]. Recently, Bianchi et al. [18] reported that fluoxetine treatment in Ts65Dn mice improves cognitive ability. Although these medications are commonly prescribed, studies have shown that fluoxetine can increase the risk of suicidal thinking/behavior [19] and that lithium can be toxic to the renal system [20]. Therefore, the potential risk of these treatments on patients with DS may outweigh the clinical benefit.

Presently, the only efficacious method for cognitive and behavioral improvement in children with DS and other intellectual disabilities is an educational plan that fosters individualized and group enrichment [21]. Early interventions stimulate various cognitive, social and sensorimotor functioning in DS individuals [22, 23]. Similar to these interventional human therapies, environmental enrichment has a stimulatory effect in rodents. Previous studies in animal models have demonstrated that environmental enrichment can increase several morphological $[24,25]$, neurochemical $[26,27]$ and behavioral aspects of brain function $[28,29]$. The underlying mechanism for these activity-dependent improvements is unclear, but environmental enrichment paradigms and physical activities have been shown to enhance adult hippocampal neurogenesis and learning ability in rodents [29-33].

The effect of environmental enrichment in the Ts65Dn mouse is not widely studied, and it is unclear whether it is possible to improve the impaired postnatal neurogenesis which results from the underlying cellular and physiological defects. However, a differential effect of enriched environment on cognitive abilities between male and female Ts65Dn mice has been reported, where the females outperform males in specific learning and memory tasks $[34,35]$. To date, the underlying mechanism(s) mediating these behavioral changes in Ts65Dn mice has/have not been elucidated. In particular, no studies have established whether environmental enrichment alters proliferation, neurogenesis and/or gliogenesis in the germinal zones of the postnatal Ts65Dn brain. Moreover, the potential differences in neuro- and/or gliogenesis between the sexes have not been addressed. Our goal was to understand the effect of enrichment and physical exercise at the cellular level to enable tailoring of the sensorimotor, cognitive and social interventional therapies to maximize benefits. Here, we determined the effect of early environmental enrichment on cell proliferation, neurogenesis and gliogenesis in the postnatal brain of both male and female Ts65Dn mice. We began the enrichment at an early time point [postnatal day 18 (P18)] corresponding to the developmental stage at which DS individuals start receiving interventional therapies.

\section{Animals and Methods}

\section{Animals}

Ts65Dn and euploid animals were generated by repeated backcross of Ts65Dn females to C57BL/6JEi $\times$ C3H/HeSnJ (B6EiC3) F1 hybrid males. The parental generation was obtained from the Jackson Laboratory (Bar Harbor, Me., USA). Tail tips were collected from all animals and genomic DNA was extracted for quantitative PCR genotyping as previously described [11].

\section{Housing and Enrichment Conditions}

The experimental design consisted of four groups of male and four groups of female mice. At P18, the male and female euploid and Ts65Dn mice were reared separately under either nonenriched (NE) or enriched (EE) conditions (euploid NE; euploid EE; Ts65Dn NE; Ts65Dn EE). The animals were subjected to enrichment for either 12 (P18-P30) or 27 (P18-P45) continuous days. NE mice were housed 3-4 per cage of a dimension of $29 \times 18 \times 12.5$ $\mathrm{cm}(\mathrm{L} \times \mathrm{W} \times \mathrm{H})$ and the same number of EE mice were housed in a rodent colony cage of a dimension of $46 \times 24 \times 15.5$ $\mathrm{cm}(\mathrm{L} \times \mathrm{W} \times \mathrm{H})$. In addition to the increased size, the EE cage was equipped with a running wheel, a rearrangeable set of plastic tubes of different textures and sizes and various toys (online suppl. fig. 1A; for all online suppl. material, see www. karger.com/doi/10.1159/000329423). Objects in the EE cage were changed every 5 days and rearranged to maintain novelty. All the groups received food and water ad libitum and were kept in a 12- 
hour light/12-hour dark cycle. All animal experiments were conducted in accordance with NIH guidelines and reviewed and approved by the institutional committee.

BrdU Injection and Tissue Processing

5-Bromo-2'-deoxyuridine (BrdU; Sigma) was dissolved in $0.9 \% \mathrm{NaCl}$ and filtered. The animals in each group received a single intraperitoneal injection of $50 \mathrm{mg} / \mathrm{kg}$ body weight for the last 6 consecutive days of their enrichment and/or nonenrichment (online suppl. fig. 1B). All the animals were sacrificed $24 \mathrm{~h}$ after the last injection. The animals were anesthetized with an intraperitoneal injection of $10 \mu \mathrm{l} / \mathrm{g}$ body weight ketamine/xylazine cocktail (100 mg ketamine and $10 \mathrm{mg}$ xylazine in $10 \mathrm{ml}$ sterile saline) and perfused intracardially with $1 \mathrm{M}$ phosphate-buffered saline (PBS, pH 7.4) followed by $4 \%$ paraformaldehyde (PFA). The brains were removed from the skulls and postfixed in PFA overnight at $4^{\circ} \mathrm{C}$. Fixed brains were cryoprotected overnight by immersion in $30 \%$ sucrose in PBS at $4^{\circ} \mathrm{C}$. All samples were embedded in Tissue-Tek OCT compound (Sakura Finetek Inc., Torrance, Calif., USA), frozen on dry ice and sectioned coronally at $20-\mu \mathrm{m}$ thickness on a cryostat (HE505E; Microm).

\section{Immunofluorescence}

The sections were washed with PBS three times, blocked with $5 \%$ normal goat serum in PBS and $0.3 \%$ Triton X-100 for $30 \mathrm{~min}$, and then incubated in primary antibodies overnight at $4^{\circ} \mathrm{C}$. After three washes in PBS, sections were incubated with secondary antibody for $1 \mathrm{~h}$ at room temperature, rinsed and mounted with Vectashield (Vector Laboratories, Burlingame, Calif., USA). The primary antibodies used were rat anti-BrdU (1:200; Abcam, Cambridge, Mass., USA), rabbit anti-Ki67 (1:500; Novacastra, Norwell, Mass., USA), NG2 chondroitin sulfate proteoglycan (1:500; Chemicon, Temecula, Calif., USA) and doublecortin (Dcx, 1:500; Abcam), mouse anti-NeuN (1:500; Chemicon) and S100 $\beta$ (1:500; Abcam). The secondary antibodies used were AlexaFluor-488-, AlexaFluor-546- and AlexaFluor-633-conjugated goat anti-rabbit, anti-rat, or anti-mouse IgG (1:200; Invitrogen, Carlsbad, Calif., USA). To double or triple stain the sections with BrdU, the immunolabeled sections were fixed in PFA for $2 \mathrm{~h}$ at $4^{\circ} \mathrm{C}$. The sections were then washed with $\mathrm{PBS}$ for three times and treated with $2 \mathrm{~N} \mathrm{HCl}$ for $30 \mathrm{~min}$ at room temperature. After a wash with PBS, the sections were treated with $0.1 \mathrm{M}$ boric acid for $15 \mathrm{~min}$ at room temperature, rinsed again in PBS, blocked and incubated with primary and secondary antibodies to BrdU as described above.

\section{Image Analysis}

All fluorescent images were taken on a LSM confocal microscope (Carl Zeiss Inc., Germany) with sequential scanning mode using $\times 10, \times 20$ or $\times 40$ objectives. Immunolabeled cells in the entire dentate gyrus (DG) and anterior subventricular zone (aSVZ) were counted every tenth section of $20 \mu \mathrm{m}$ each (every 200 $\mu \mathrm{m})$ in all animals using LSM 510 software packages. Total number of BrdU+, BrdU+NeuN+, BrdU+Dcx+, BrdU+S100 $\beta+$ and BrdU+NG2+ cells were counted along the entire volume of DG or aSVZ (online suppl. tables 1 and 2). Briefly, each cell was analyzed in its entire $\mathrm{z}$-axis in order to exclude false double-labeling due to an overlay of signals from different cells. The total number of cells was estimated by multiplying the number counted in the series of sampled sections by the inverse of the section sampling fraction $(\mathrm{SSF}=1 / 10)$. In addition, the rate of neuron formation was deter- mined by dividing the number of BrdU+NeuN+ or BrdU+Dcx+ cells by the number of BrdU+ cells within each individual group. Similar analysis was performed for the BrdU+S100 $\beta+$ and $\mathrm{BrdU}+\mathrm{NG} 2+$ cells to express the rate of gliogenesis.

\section{Statistical Analysis}

Data are presented as mean \pm SEM. All data were analyzed in GraphPad Prism 5 software using two-way ANOVA with treatment (NE, EE) and genotype (euploid, Ts65Dn) as factors, followed by post hoc testing using the Bonferroni method. Unpaired Student's t tests were also used to assess differences between agematched cohorts for a single time point. A probability level of $\mathrm{p}<$ 0.05 was considered to be statistically significant.

\section{Results}

\section{Effect of Enriched Environment on Ts65Dn Mice \\ Body Weight}

To determine the general effect of environmental enrichment on Ts65Dn animals, we measured the change in body weight of the euploid and Ts65Dn mice during the process of enrichment. Similar measurements were taken for NE mice of the same age. We found that at P18, the average body weight of euploid and Ts65Dn animals was similar. Enrichment for 12 days (P18-P30) caused a 20 and 25\% weight gain in male euploid and Ts65Dn animals, respectively, when compared to the age- and sex-matched corresponding NE groups (table 1). Similarly, a longer period of enrichment (P18-P45) caused a 16 and 29\% weight gain in male euploid and Ts65Dn animals, respectively (table 1). On the contrary, the EE female mice showed no difference in weight gain when compared to their NE groups (table 1). These results indicate that environmental enrichment and wheel running specifically increased the body weight of male mice, irrespective of their genotype, which may result from increased muscle mass $[36,37]$. Although some previous studies have reported that EE mice had lighter body weights, the variation in our results suggests that strain, sex and age differences may be contributing factors [38].

\section{Environmental Enrichment Increases Cell}

Proliferation in Ts65Dn Hippocampus

The DG of the hippocampus is one of the two neurogenic zones of the postnatal brain. Previous studies have shown that hippocampal cell proliferation and neurogenesis is impaired in Ts65Dn mice [1, 17]. To understand how voluntary physical activity and enriched environment influence the generation of new neurons in the Ts65Dn DG and to determine whether these stim- 
Fig. 1. Effect of environmental enrichment and physical exercise on cell proliferation in the DG of euploid and Ts65Dn mice. a Representative sections immunostained for BrdU from brains of P30 male mice with (EE) and without enrichment (NE). BrdU+ cells are found to be present throughout the DG in all the groups. b Number of BrdU+ cells (expressed as percent of euploid-NE) in the DG of male euploid and Ts65Dn mice subjected to non-enriched and enriched environments for short- (P18-P30) and long-term (P18$\mathrm{P} 45)$ periods. c Number of BrdU+ cells (expressed as percent of euploid-NE) in the DG of female euploid and Ts65Dn mice subjected to non-enriched and enriched environments for short- and long-term periods. The results indicate that environmental enrichment together with physical exercise completely restores proliferation in both male and female Ts65Dn DG to the respective euploid level. Data points represent mean \pm SEM $(n=4$ mice for each age and group). ${ }^{*} \mathrm{p}<0.05$; unpaired Student's t test. Scale bar: $100 \mu \mathrm{m}$.
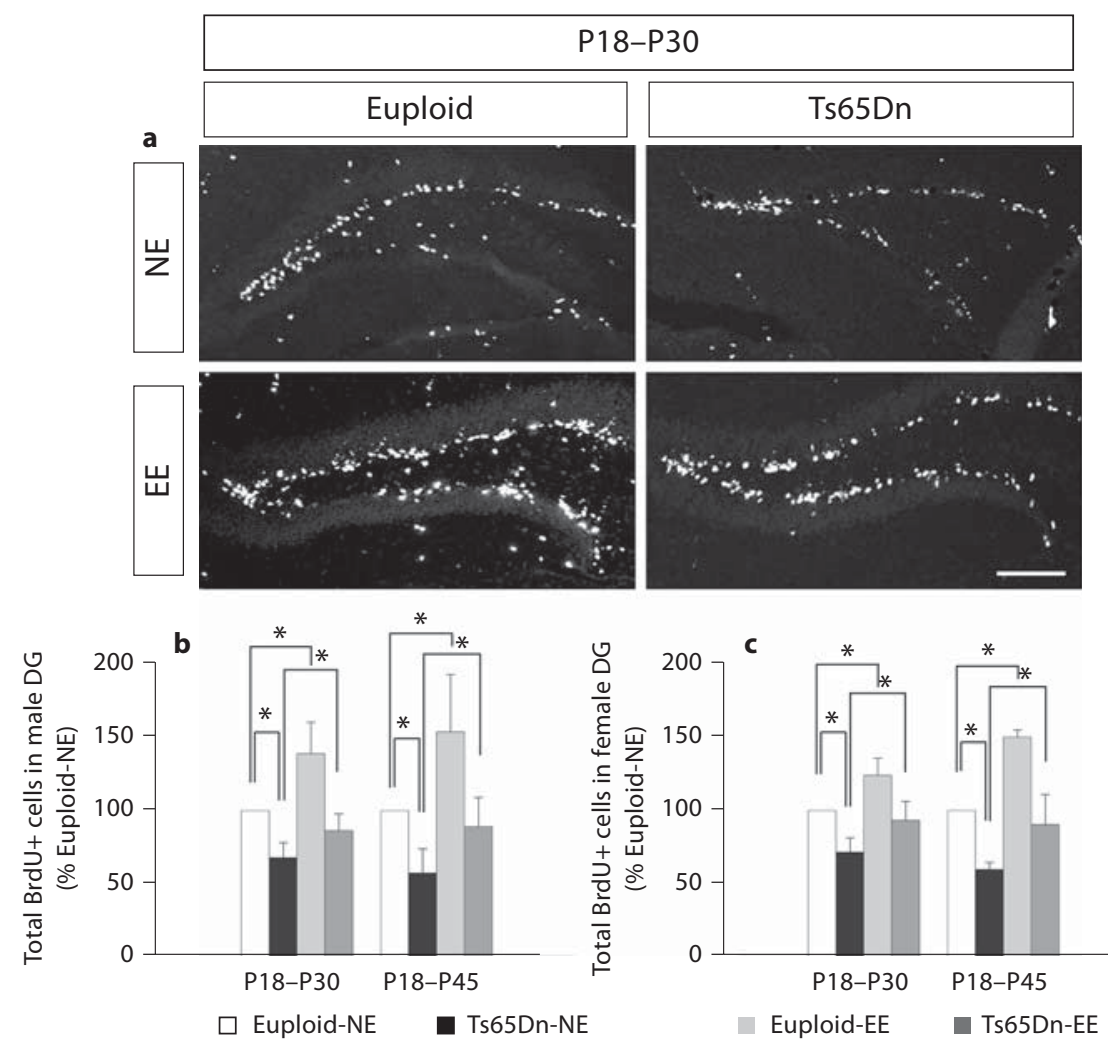

Table 1. Change in body weight (in grams)

\begin{tabular}{|c|c|c|c|c|c|c|c|c|}
\hline \multirow[t]{3}{*}{ Sex } & \multicolumn{4}{|l|}{ P18-P30 } & \multicolumn{4}{|l|}{ P18-P45 } \\
\hline & \multicolumn{2}{|l|}{ euploid } & \multicolumn{2}{|l|}{ Ts65Dn } & \multicolumn{2}{|l|}{ euploid } & \multicolumn{2}{|l|}{ Ts65Dn } \\
\hline & $\mathrm{NE}$ & $\mathrm{EE}$ & $\mathrm{NE}$ & $\mathrm{EE}$ & $\mathrm{NE}$ & $\mathrm{EE}$ & $\mathrm{NE}$ & $\mathrm{EE}$ \\
\hline Male & $9.6 \pm 0.8$ & $11.5 \pm 0.37^{*}$ & $6.9 \pm 0.35$ & $8.7 \pm 0.8$ & $11.9 \pm 0.35$ & $13.8 \pm 0.45^{*}$ & $11.3 \pm 0.56$ & $14.6 \pm 1.27^{*}$ \\
\hline Female & $6.8 \pm 0.5$ & $8.2 \pm 0.75$ & $5.9 \pm 0.65$ & $7.5 \pm 0.5$ & $11.5 \pm 1.05$ & $11.8 \pm 0.5$ & $10.6 \pm 1.5$ & $11.5 \pm 1$ \\
\hline
\end{tabular}

Data represent mean $\pm \mathrm{SD} .{ }^{*} \mathrm{p}<0.04$, significantly different from NE groups.

uli have any differential effect on male and female mice, we compared the proliferation and phenotype of the hippocampal progenitor cells in NE and EE groups of both male and female mice. We administered BrdU daily on the last 6 days of enrichment as previously reported $[16,17,39]$.

Proliferation was assessed by measuring the number of BrdU-labeled cells in the entire volume of DG. After 6 daily BrdU injections in the NE conditions, we found a large number of BrdU+ cells in the DG (fig. 1, online suppl. fig. 2). In a standard living condition, both male and female Ts65Dn mice had less BrdU+ cells ( -32 and $-29 \%$, respectively, at $\mathrm{P} 30$, and -42 and $-40 \%$, respectively, at P45) in the DG compared to age-matched euploid mice (fig. 1a-c). Two-way ANOVA for the shortterm (12 days) EE groups revealed a genotype effect for 
Fig. 2. Effect of environmental enrichment and physical exercise on neurogenesis in the DG of euploid and Ts65Dn mice. a Representative sections immunostained for BrdU and NeuN from brains of P30 male mice with (EE) and without enrichment (NE). BrdU+NeuN+ cells represent the number of neurons formed during the last 6 days of the EE or NE condition. b Number of BrdU+NeuN+ cells (expressed as percent of euploid-NE) in the DG of male euploid and Ts65Dn mice subjected to non-enriched and enriched environments for short- (P18-P30) and longterm (P18-P45) periods. c Number of $\mathrm{BrdU}+\mathrm{NeuN}+$ cells (expressed as percent of euploid-NE) in the DG of female euploid and Ts65Dn mice subjected to non-enriched and enriched environments for short- and long-term periods. The results indicate that environmental enrichment together with physical exercise rescues neurogenesis defect in both male and female Ts65Dn DG. Data points represent mean \pm SEM $(n=4$ mice for each age and group). ${ }^{*} \mathrm{p}<0.05$; unpaired Student's t test. Scale bar: $50 \mu \mathrm{m}$.

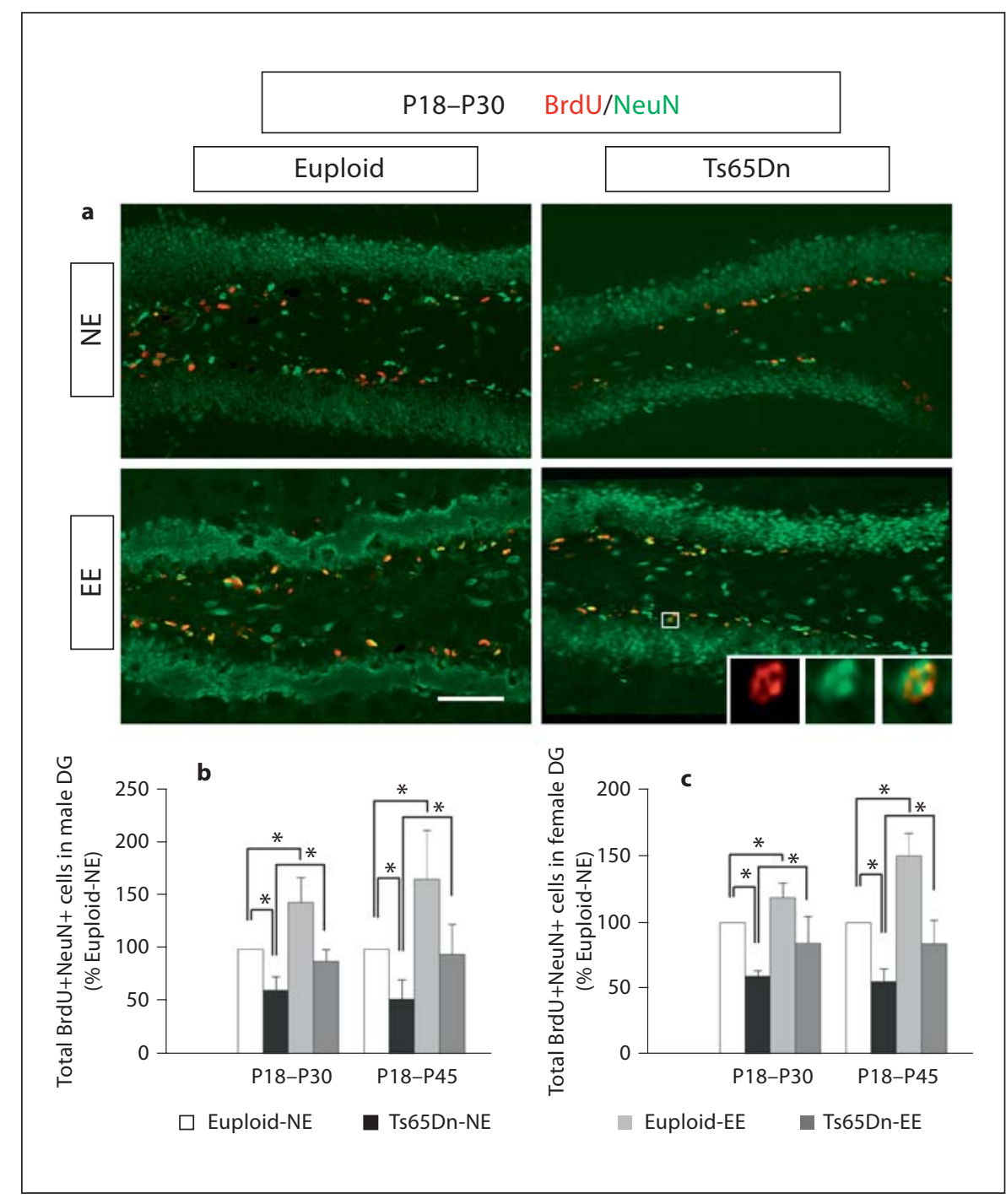

Fig. 3. Effect of environmental enrichment and physical exercise on gliogenesis in the DG of euploid and Ts65Dn mice. a Representative sections immunostained for BrdU and $S 100 \beta$ from brains of P30 male mice with (EE) and without enrichment (NE). $\mathrm{BrdU}+\mathrm{S} 100 \beta+$ cells represent the number of glial cells formed during the last 6 days of the EE or NE condition. b Number of BrdU+S100 $\beta+$ cells (expressed as percent of euploid-NE) in the DG of male euploid and Ts65Dn mice subjected to non-enriched and enriched environment for short- (P18-P30) and long-term (P18-P45) periods. $c$ Number of BrdU+S100 $\beta+$ cells (expressed as percent of euploid-NE) in the DG of female euploid and Ts65Dn mice subjected to non-enriched and enriched environments for short- and long-term periods. d Representative sections immunostained for BrdU and NG2 from brains of P30 male mice with
(EE) and without enrichment (NE). BrdU+NG2+ cells represent the number of oligodendrocyte progenitor cells formed during the last 6 days of the EE or NE condition. e Number of BrdU+NG2+ cells (expressed as percent of euploid-NE) in the DG of male euploid and Ts65Dn mice subjected to non-enriched and enriched environments for short- (P18-P30) and long-term (P18-P45) periods. $\mathbf{f}$ Number of BrdU+NG2+ cells (expressed as percent of euploid-NE) in the DG of female euploid and Ts65Dn mice subjected to non-enriched and enriched environments for short- and long-term periods. The results indicate that 4 weeks of environmental enrichment and physical exercise increase gliogenesis in both male and female Ts65Dn DG. Data points represent mean \pm SEM ( $\mathrm{n}=4$ mice for each age and group). ${ }^{*} \mathrm{p}<0.05$; unpaired Student's t test. Scale bar: $50 \mu \mathrm{m}$. 

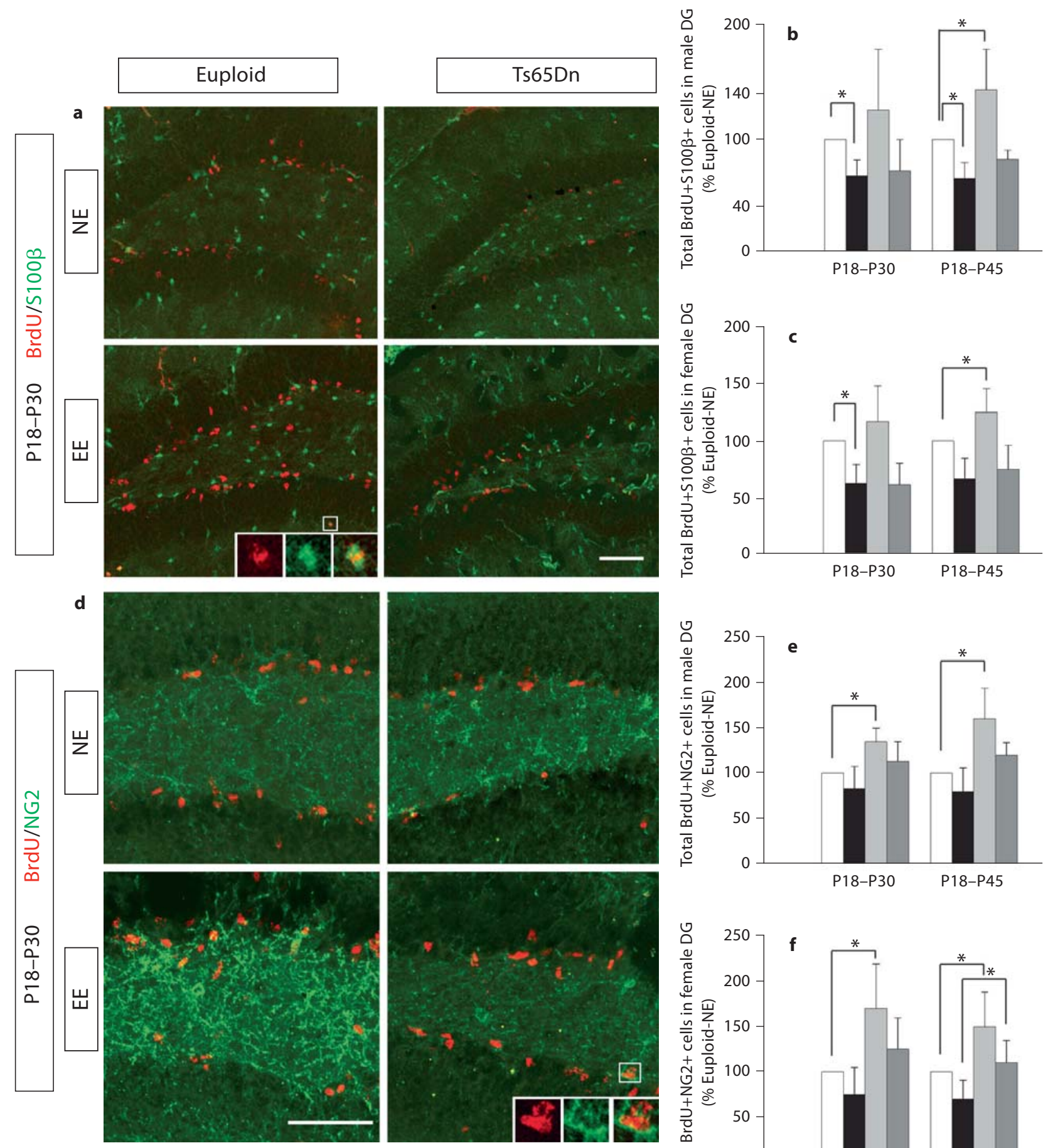

$\square$ Euploid-NE

- Ts65Dn-NE
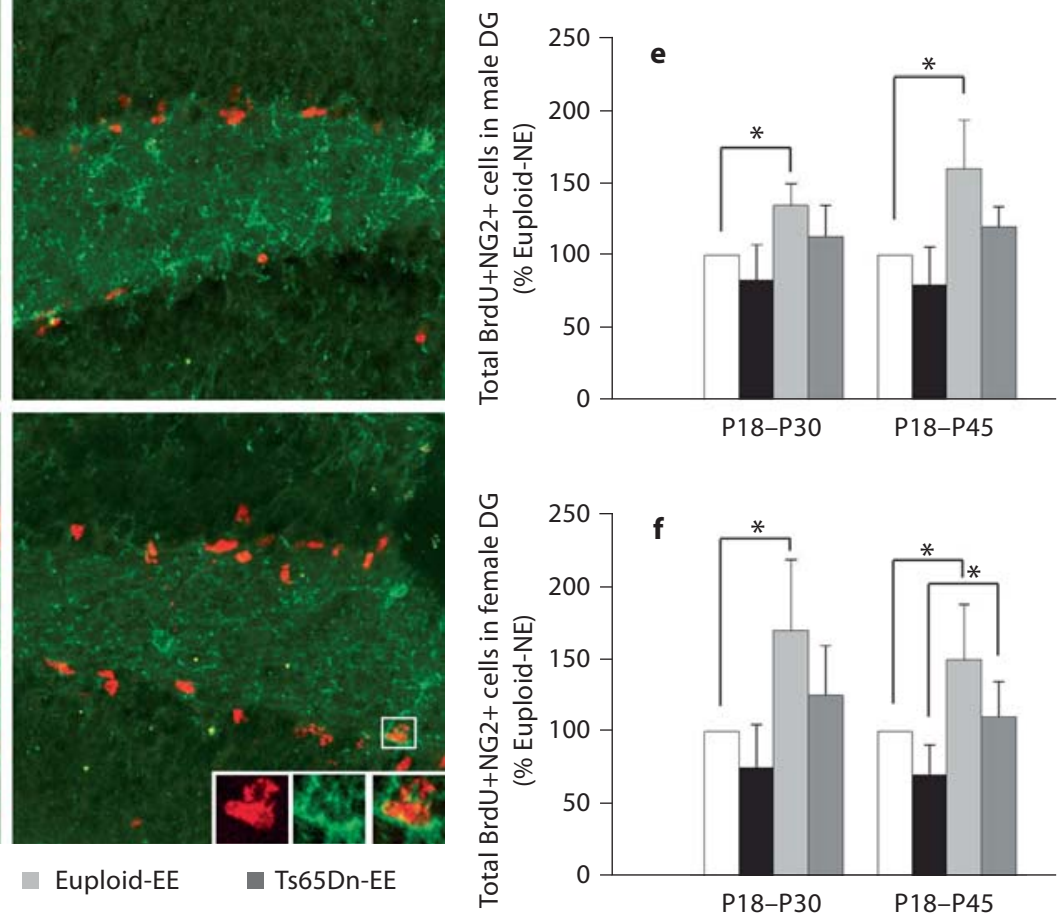
both male $[\mathrm{F}(1,14)=36.6 ; \mathrm{p}<0.001]$ and female $[\mathrm{F}(1$, 12) $=38.07 ; \mathrm{p}<0.001]$, as well as an effect of enrichment on male $[\mathrm{F}(1,14)=20.2 ; \mathrm{p}=0.0005]$ and female $[\mathrm{F}(1,12)=$ $21.91 ; p=0.0005]$ with no genotype $\times$ enrichment interaction, indicating overall differences in the number of BrdU+ cells between the EE and NE groups of mice. A similar effect was found for the long-term (4 weeks) EE groups of mice. In addition, for both time periods, enrichment markedly increased the number of BrdU-labeled cells in male euploid ( +38 and $+53 \%$, respectively) and Ts65Dn (+27 and $+55 \%$, respectively) DG (fig. 1b). Interestingly, although male EE Ts65Dn mice had less BrdU-labeled cells than EE euploid mice, exposure to the enriched environment increased proliferation in EE Ts65Dn hippocampus to equal the level found in the NE euploid controls (fig. 1b). A similar effect of enrichment on the number of BrdU-labeled cells was observed in the DG of female euploid and Ts65Dn mice (fig. 1c). To determine the effect of enrichment on the size of the total proliferating population, we estimated the total number of the actively dividing cell population in DG by using Ki67 immunohistochemistry [40, 41]. We found that the male Ts65Dn DG normally has a smaller pool of Ki67+ cells ( $-21 \%$ at $\mathrm{P} 30$ and $-41 \%$ at $\mathrm{P} 45)$ compared to the male euploid mice (online suppl. fig. 3). Environmental enrichment increased the number of Ki67+ cells in both groups [genotype effect: $\mathrm{F}(1,12)=12.14, \mathrm{p}=0.0045$ at $\mathrm{P} 30$ and $\mathrm{F}(1,12)=10.74, \mathrm{p}=0.0066$ at $\mathrm{P} 45$; enrichment effect: $\mathrm{F}(1$, $12)=26.45, \mathrm{p}=0.0002$ at $\mathrm{P} 30$ and $\mathrm{F}(1,12)=17.54, \mathrm{p}=$ 0.0013 at P45], and comparison of EE Ts65Dn mice with $\mathrm{NE}$ euploid mice again showed no difference between groups (online suppl. fig. 3). Taken together, these results indicate that both short- and long-term enriched environment together with physical exercise completely restore proliferation in the Ts65Dn DG to the control euploid level, and that the effect is comparable between male and female mice.

\section{Effect of Enrichment on Neurogenesis and Gliogenesis} in Ts65Dn Hippocampus

To determine the neuronal or glial phenotype of the cells in the DG formed during the last 6 days of enrichment, we measured the number of cells colabeled with BrdU and NeuN for new neurons, and cells colabeled with BrdU and either S100 $\beta$ (marker for both astrocytes and oligodendrocytes) or NG2 (marker for early oligodendrocyte progenitor cells) for glia $[42,43]$. We found more BrdU+NeuN+ than BrdU+S100 $\beta+$ cells in the DG of all groups of mice (online suppl. fig. 4 and 5). Moreover, the NE male and female Ts65Dn DG had fewer
BrdU $+\mathrm{NeuN}+$ cells $(-38$ and $-40 \%$, respectively, at P30 and -47 and $-44 \%$, respectively, at $\mathrm{P} 45$ ) compared to that of the age- and sex-matched NE euploid mice (fig. 2a-c), indicating reduced neurogenesis in Ts65Dn DG under standard living conditions. A combination of enriched environment and wheel running increased the number of BrdU+NeuN+ cells by $44 \%$ in both euploid and Ts65Dn male mice in the short-term condition compared to the NE groups of mice (fig. 2b). Statistical analysis for this age group of male mice revealed effects of both genotype $[\mathrm{F}(1,12)=35.26 ; \mathrm{p}<0.0001]$ and treatment $[\mathrm{F}(1,12)=$ $21.59 ; \mathrm{p}=0.0006]$ with no genotype $\times$ enrichment interaction indicating overall differences in the number of newly generated neurons between the EE and NE groups of mice. Long-term enrichment had a similar effect on the number of neurons formed in the DG of male mice (fig. 2b). Comparable effects of short- and long-term enriched environment on neuron formation were also observed in the DG of female mice (fig. 2c). In addition, comparison of both male and female EE Ts65Dn mice and NE euploid mice showed no difference in the number of BrdU+NeuN+ cells (fig. 2b, c), indicating that environmental enrichment rescued the neurogenesis defect in the DG of Ts65Dn mice.

Short-term enrichment had no significant effect on the number of BrdU+S100 $\beta+$ cells in DG irrespective of the sex and genotypes of the mice, whereas long-term enrichment resulted in a significant effect of genotype $[\mathrm{F}(1,16)=34.71 ; \mathrm{p}<0.0001$ in male; $\mathrm{F}(1,12)=14.49 ; \mathrm{p}=$ 0.0025 in female $]$ and of treatment $[\mathrm{F}(1,16)=17.19 ; \mathrm{p}=$ 0.0008 only in male] with no genotype $\times$ enrichment interaction. Post hoc tests revealed an increase in the number of BrdU+S100 $\beta+$ cells only in euploid male $(+44 \%)$ and female $(+25 \%)$ mice living in a long-term enriched environment (fig. $3 \mathrm{a}-\mathrm{c}$ ). In addition, both shortand long-term enrichment resulted in a significant increase in the co-labeling of BrdU with the oligodendrocyte progenitor cell marker NG2 in both male and female euploid mice (fig. $3 \mathrm{~d}-\mathrm{f}$ ). These results suggest that enrichment and physical exercise promote a gliogenic response in the DG of the hippocampus of euploid mice, while the gliogenesis in Ts65Dn mice remains unresponsive to the enriched environment. Finally, the unaltered rates of neurogenesis and gliogenesis by environmental enrichment (online suppl. fig. 4B, C, 5B, C) can be explained by the presence of more BrdU+ proliferating cells under the EE condition. 
Fig. 4. Effect of environmental enrichment and physical exercise on cell proliferation in the aSVZ of euploid and Ts65Dn mice. a Representative sections immunostained for BrdU from brains of P30 male mice with (EE) and without enrichment (NE). BrdU+ cells are found to be present in the aSVZ in all the groups. b Number of BrdU+ cells (expressed as percent of euploid-NE) in the aSVZ of male euploid and Ts65Dn mice subjected to non-enriched and enriched environments for short(P18-P30) and long-term (P18-P45) periods. c Number of BrdU+ cells (expressed as percent of euploid-NE) in the aSVZ of female euploid and Ts65Dn mice subjected to non-enriched and enriched environments for short- and long-term periods. The results indicate that only long-term environmental enrichment together with physical exercise completely restores proliferation in the female Ts65Dn SVZ to the euploid level, whereas the enriched Ts65Dn males have a significant proliferation deficit in aSVZ even after long-term exposure to enrichment. Data points represent mean \pm SEM ( $\mathrm{n}=4$ mice for each age and group). ${ }^{*} \mathrm{p}<0.05$; unpaired Student's t test. Scale bar: $50 \mu \mathrm{m}$. LV = Lateral ventricle; $\mathrm{ST}=$ striatum; $\mathrm{WM}=$ white matter.

\section{P18-P30}
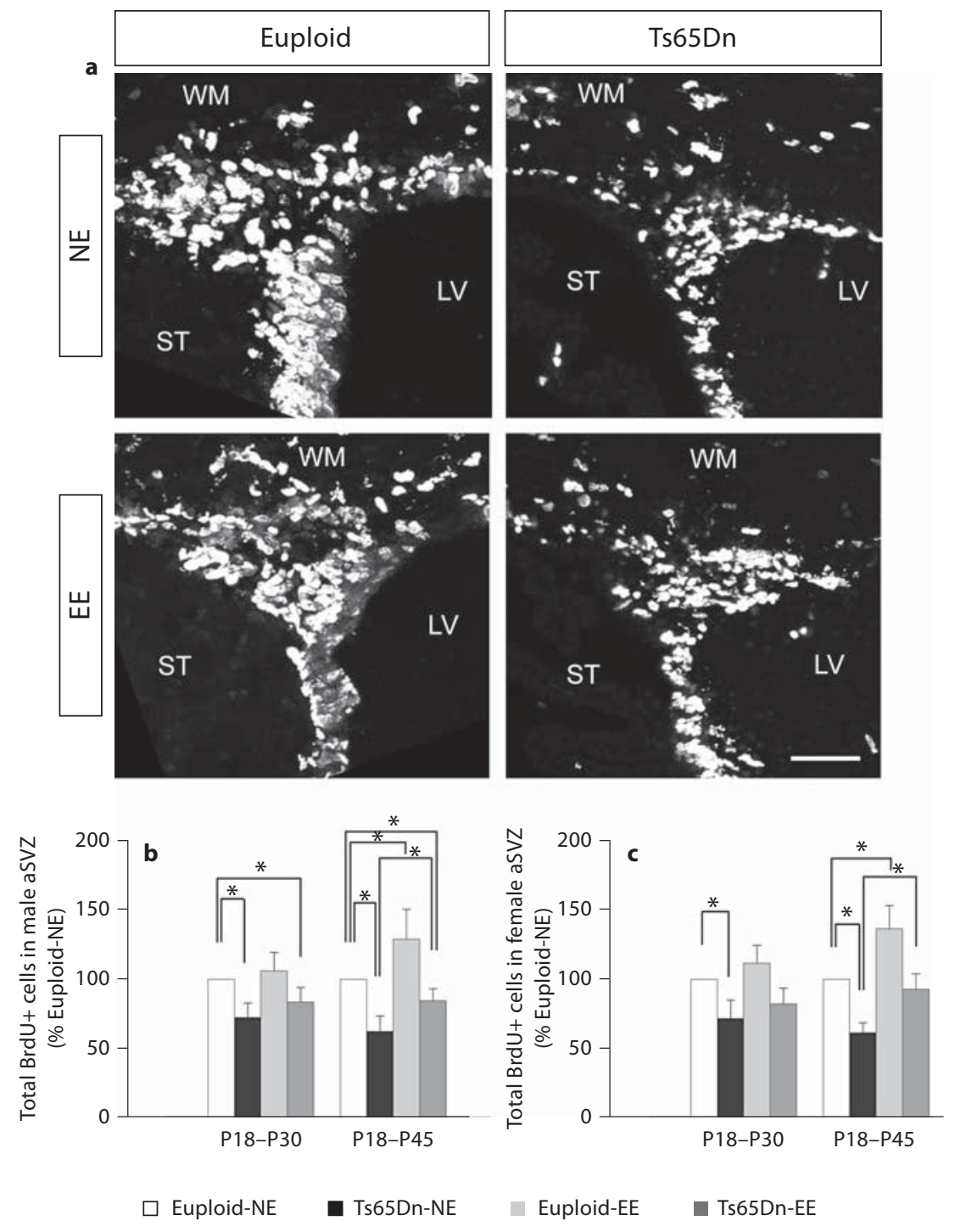

\section{Environmental Enrichment Increases Cell}

\section{Proliferation in Ts65Dn SVZ}

Similar to the DG, the SVZ of the postnatal mammalian brain is also a major neurogenic niche. A recent study reported reduced cell proliferation and neurogenesis in the SVZ of Ts65Dn mice [16]. To determine if the combination of enriched environment and voluntary physical activity has any effect on the generation of new neurons in Ts65Dn SVZ, we examined the proliferation of the progenitor cells and their phenotype in the aSVZ with similar methods as in the hippocampus.

Quantification of the number of BrdU+ cells showed that under standard living conditions, male and female Ts65Dn mice had less BrdU+ cells $(-27$ and $-28 \%$, respectively, at P30, and -37 and $-38 \%$, respectively, at P45) in the aSVZ compared to the age- and sex-matched euploid littermate mice (fig. $4 \mathrm{a}-\mathrm{c}$ ). Unlike DG, we also found that the number of BrdU+ cells in the aSVZ of either euploid 
or Ts65Dn male and female mice was not affected by short-term enrichment (fig. 4b, c). However, enrichment for 4 weeks had a significant effect of genotype $[\mathrm{F}(1$, $12)=39.85 ; \mathrm{p}<0.0001]$ and treatment $[\mathrm{F}(1,12)=16.91$; $\mathrm{p}=0.0014]$ in male mice with no genotype $\times$ enrichment interaction. Post hoc tests revealed an increased number of BrdU-labeled cells in the aSVZ of both euploid (+29\%) and Ts65Dn (+35\%) male mice (fig. 4a, b). A similar effect of enrichment on the number of BrdU-labeled cells was observed in the aSVZ of female euploid and Ts65Dn mice (fig. 4c). Moreover, after long-term environmental enrichment, the number of BrdU+ cells was comparable between EE female Ts65Dn mice and NE female euploid mice (fig. 4c), indicating that the proliferation deficit is restored in female Ts65Dn mice after 4 weeks of stimulated environment. However, unlike females, the male Ts65Dn mice lacked a robust response in the aSVZ following the longterm EE condition since significantly fewer $(-16 \%)$ BrdU+ cells were found compared to the NE euploid mice (fig. 4b). To determine the effect of enrichment on the size of the total proliferating population in aSVZ, we measured the number of Ki67+ cells in male mice. We found fewer Ki67+ cells in Ts65Dn than in euploid mice (online suppl. fig. 3). Statistical analysis determined that although longterm enrichment increased the number of Ki67+ cells in both euploid and Ts65Dn aSVZ, a comparison of EE Ts65Dn mice with NE euploid mice showed a lasting and significant decrease in the Ts65Dn brain (online suppl. fig. 3). Taken together these results suggest that 4 weeks of enriched environment restores proliferation in female Ts65Dn SVZ to control level, while the SVZ cells of male Ts65Dn mice are not as responsive to the stimuli.

Fig. 5. Effect of environmental enrichment and physical exercise on neurogenesis and gliogenesis in the aSVZ of euploid and Ts65Dn mice. a Representative sections immunostained for BrdU and Dcx from brains of P30 male mice with (EE) and without enrichment (NE). BrdU+Dcx+ cells represent the number of neurons formed in the aSVZ during the last 6 days of the EE or NE condition. b Number of BrdU+Dcx + cells (expressed as percent of euploid-NE) in the aSVZ of male euploid and Ts65Dn mice subjected to non-enriched and enriched environments for short- (P18-P30) and long-term (P18-P45) periods. c Number of BrdU+Dcx+ cells (expressed as percent of euploid-NE) in the aSVZ of female euploid and Ts65Dn mice subjected to non-enriched and enriched environments for short- and long-term periods. The results indicate that long-term environmental enrichment together with physical exercise rescues neurogenesis defect only in female Ts65Dn SVZ, while the enriched Ts65Dn males have significantly less neurons than the non-enriched euploid

\section{Effect of Environmental Enrichment on Neurogenesis} and Gliogenesis in Ts65Dn SVZ

To determine if the increase in SVZ proliferation due to environmental enrichment has any effect on new neuron formation, we estimated the number of BrdU and Dcx double-positive cells in the aSVZ. Unlike DG, NeuN+ mature neurons are not found in the SVZ; only Dcx+ immature neurons can be detected. Previous studies have shown that voluntary physical exercise has a stimulatory effect on the Dcx population of cells in the hippocampus [44, 45]. No studies to date have assessed the effect of environmental enrichment on Dcx expression in the SVZ. In this study, we found that both male and female NE Ts65Dn mice had fewer BrdU+Dcx+ cells $(-33$ and $-29 \%$ at P30, and -41 and $-40 \%$ at $\mathrm{P} 45$, respectively) in the aSVZ compared to NE euploid mice (fig. 5; online suppl. fig. 6). Twoway ANOVA for long-term enrichment displayed a genotype effect for both male $[\mathrm{F}(1,12)=38.58 ; \mathrm{p}<0.0001]$ and female $[F(1,16)=66.77 ; p<0.0001]$, as well as an effect of enrichment on male $[F(1,12)=17.75 ; p=0.0012]$ and female $[F(1,16)=30.58 ; \mathrm{p}<0.0001]$ with no genotype $\times$ enrichment interaction indicating overall differences in the number of BrdU+Dcx+ cells between the EE and NE groups of mice. Post hoc tests revealed that enrichment for 4 weeks increased the number of newly generated neurons in both euploid $(+30 \%$ in male and $+34 \%$ in female) and Ts65Dn (+38\% in male and $45 \%$ in female) mice (fig. $5 \mathrm{~b}$, c). Furthermore, comparison of long-term EE Ts65Dn mice and NE euploid mice showed a restoration in the number of BrdU+Dcx+ cells in Ts65Dn females, but it revealed $18 \%$ fewer BrdU+Dcx+ cells in EE Ts65Dn males than NE euploids (fig. 5b, c), indicating that 4 weeks of

males. d Representative sections immunostained for BrdU and NG2 from brains of P30 male mice with (EE) and without enrichment (NE). BrdU+NG2+ cells represent the number of oligodendrocyte progenitor cells formed during the last 6 days of the EE or NE condition. e Number of BrdU+NG2+ cells (expressed as percent of euploid-NE) in the aSVZ of male euploid and Ts65Dn mice subjected to non-enriched and enriched environments for short- (P18-P30) and long-term (P18-P45) periods. f Number of BrdU+NG2+ cells (expressed as percent of euploid-NE) in the aSVZ of female euploid and Ts65Dn mice subjected to non-enriched and enriched environments for short- and long-term periods. The results indicate that long-term environmental enrichment together with physical exercise increases gliogenesis in both male and female Ts65Dn SVZ. Data points represent mean \pm SEM ( $n=4$ mice for each age and group). ${ }^{*} \mathrm{p}<0.05$; unpaired Student's t test. Scale bar: $50 \mu \mathrm{m}$. LV = Lateral ventricle; ST = striatum; $\mathrm{WM}=$ white matter. 


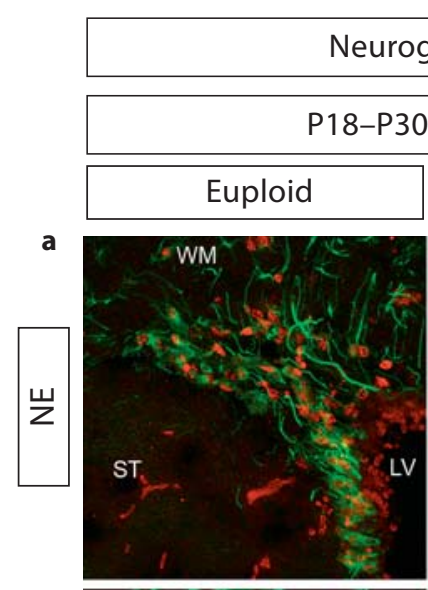

eurogenesis
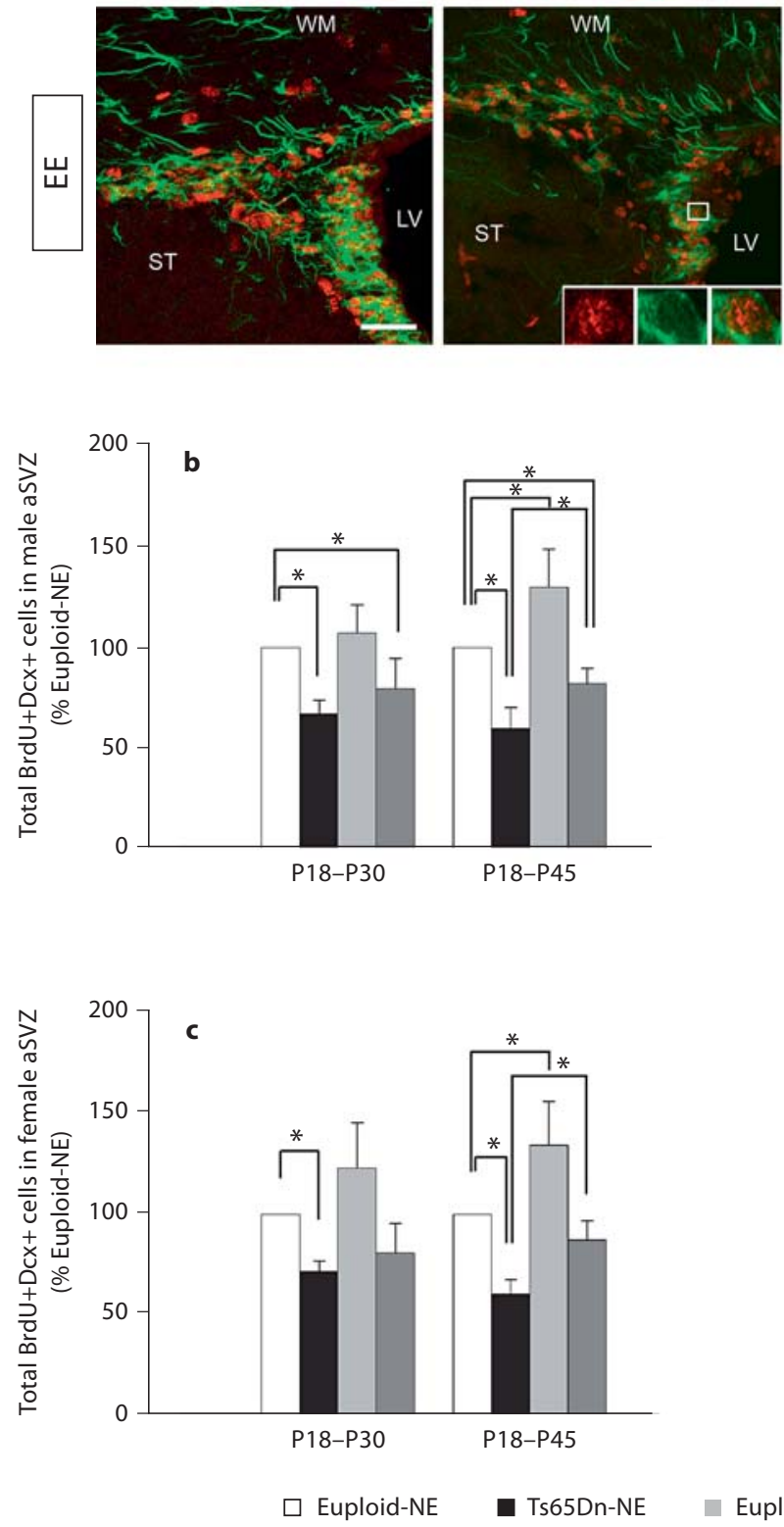

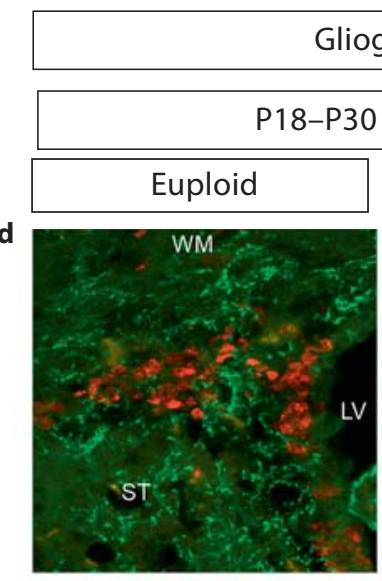

Gliogenesis
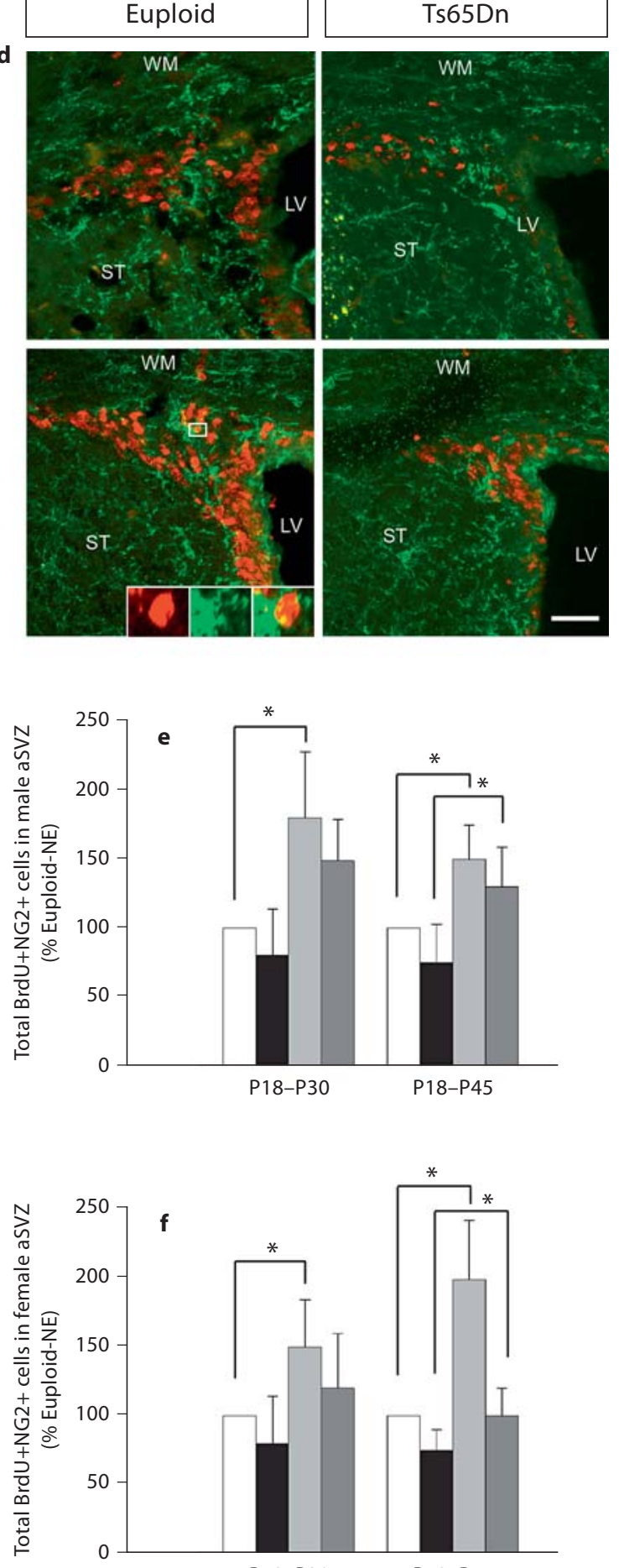

P18-P30

P18-P45 
stimulated environment fully rescued the neurogenesis defect in the SVZ of only female Ts65Dn mice.

To evaluate whether environmental enrichment had any effect on gliogenesis in the aSVZ, we analyzed the number of cells co-expressing BrdU with either $S 100 \beta$ or NG2. Unlike in the DG, we did not find co-expression of $\mathrm{BrdU}$ and S100 $\beta$ in cells in the aSVZ. Also, we found no difference between NE Ts65Dn and NE euploid mice in the number of BrdU+NG2+ cells in the aSVZ of either male or female mice (fig. 5d-f). Short- and long-term enriched environment resulted in a significant effect of enrichment for both male $[\mathrm{F}(1,12)=16.33 ; \mathrm{p}=0.0016$, for short term; $F(1,12)=32.67 ; p<0.0001$, for long term] and female $[F(1,12)=7.73 ; p=0.017$, for short term; $F(1,12)=$ $20.25 ; p=0.002$, for long term], with no effect of genotype or genotype $\times$ enrichment interaction (fig. $5 d-f$ ), indicating that environmental enrichment affects gliogenesis in the SVZ of euploid and Ts65Dn mice to the same extent. Similar to the DG, environmental enrichment was found to have no significant effect on the rate of neurogenesis or gliogenesis in the aSVZ in all the groups (online suppl. fig. 6).

\section{Discussion}

This study demonstrates for the first time that sensorimotor environmental enrichment results in enhanced neural cell proliferation, as well as neurogenesis and gliogenesis in the germinal zones of the postnatal Ts65Dn mouse brain. The DG cells of both male and female Ts65Dn mice respond similarly to these stimulatory environments. We found that both short-term (P18-P30) and long-term (P18-P45) enrichment stimulated neurogenesis by enhancing progenitor proliferation in the hippocampus of euploid and Ts65Dn mice. However, only long-term enrichment has a stimulatory effect on gliogenesis in this region. Unlike in the DG, the neuronal progenitor cells in the aSVZ of female Ts65Dn mice responded to enriched environment earlier than the males. The effect of enrichment on gliogenesis in the aSVZ was similar in both sexes which occurred only after prolonged exposure to EE conditions. The clinical implications of these results are that similar cellular changes are likely occurring in the DS brain in response to early intervention, and that this may be more effective and safe than the use of medications $[16,17]$.

Environmental enrichment is an experimental model which potentiates social interaction and sensorimotor stimulation in animals $[46,47]$. As a result of living in these conditions compared to 'typical' rodent housing, the brain undergoes morphological and molecular changes. Previous studies have shown that enriched environment and physical activity consistently increased adult neurogenesis and restored memory functioning in normal as well as diseased mouse models [31, 39, 48, 49]. Improved cognitive ability under conditions that stimulate neurogenesis and synaptic plasticity, such as enrichment and running strongly imply that the newly formed neurons functionally integrate into the appropriate neural circuits to enhance cognitive function [30, 31, 46]. Early oligodendrocyte progenitor cell expansion is also known to occur after environmental enrichment; however, this effect has been shown in animal models of brain injury [50]. In our murine model of a genetic condition, the functional significance of increased gliogenesis after enrichment is unclear and is currently under investigation, but it may be that the newly formed cadre of neurons requires additional numbers of glial cells for functional maturation and maintenance.

Our novel results indicate the competent role of enriched environment and physical exercise in the regulation of postnatal neurogenesis and neuroplasticity in the DS brain, which may have a functional relevance. In fact, the more rapid and robust response of the hippocampus to environmental enrichment when compared to the SVZ strengthens the fact that these stimuli are beneficial in restoring hippocampus-dependent learning and memory function in Ts65Dn mice [35]. In addition, the delayed effect of enrichment and running on SVZ neurogenesis suggests that the generation of new neurons may be lo$\mathrm{cal}$ and region-specific. Although a possible molecular mechanism underlying the cellular changes which result in impaired DS brain has recently been reported [51], no commendable/beneficial therapeutic interventions are available to ameliorate the cognitive impairment. Our current study suggests that it is possible to restore proliferation, neurogenesis and gliogenesis in the hippocampus and SVZ of an animal model of DS by housing the animals in an enriched environment with voluntary physical exercise. Comparing our results from the shortand long-term exposures, our study strongly suggests a positive relationship between duration of enriched environment exposure and the magnitude of proliferation effects. This indicates that enrichment and cognitive/behavioral intervention programs can be tailored to have specific amounts of brain response. Further studies are now needed to determine whether these cellular changes from short- and long-term enrichment correlate with cognitive performance. 
Environmental enrichment has been shown to increase memory and learning ability in female Ts65Dn mice, while male Ts65Dn mice have comparatively weaker performance [34]. However, here we show that there are only minimal gender differences, if any, in the effect of enrichment on neurogenesis and proliferation in the hippocampus of both euploid and Ts65Dn mice. This contradiction may be explained by the fact that Martinez-Cue et al. [34] only used enriched environment and no physical exercise. In our present study, enriched environment consisted of toys, tubes and a running wheel. It is assumed that these additional stimuli may affect different populations of precursor cells. For example, physical exercise stimulates neurogenesis by increasing the proliferation of type 2 a progenitor cells [52], while enrichment primarily supports neuronal survival [30]. Mirochnic et al. [53] have also shown that, under acute conditions, enrichment also induces proliferation of late progenitor cells like type $2 \mathrm{~b}$ and type 3 . In this study, we demonstrate that a combination of environmental enrichment and voluntary exercise is sufficient to cause a robust response in the neural precursor proliferation in postnatal male and female Ts65Dn mice. Therefore, it is likely that environmental enrichment and physical exercise together may increase cognitive ability in male Ts65Dn mice, which otherwise exhibit deteriorated cognitive function under standard enriched environment [34]. The distinctive early effect of enrichment and wheel running on female Ts65Dn SVZ proliferation and neuro- genesis suggests a potential role of sex hormones such as estrogen on these cellular changes $[54,55]$. In fact, in animal models of brain injury, it has been shown that there is a gender-based difference in the response of SVZ cells on proliferation after the injury [56]. Our results, therefore, reinforce the need to study the cellular and behavioral responses of treatment paradigms in both sexes in order to design specific interventional strategies.

DS is the most common genetic cause of intellectual disability today. With its high incidence and the increased societal integration of DS individuals, there is a need to implement programs to improve the cognitive abilities of DS individuals. Sensory, social and motor enrichment paradigms are possibly the best means to normalize cognitive function. The Ts65Dn mouse is an ideal model to investigate the relationship between enrichment and plasticity of the developing DS brain and to provide the basis for intervention tools to improve behavioral deficits of DS individuals.

\section{Acknowledgements}

This work was supported by National Institute of Health grants RO1 HD057580 to T.F.H., RO1 NS045702 and RO1 NS056427 and PO1NS062686 to V.G., and K12 NS052 and HD001399 to J.S.; the Intellectual and Developmental Disabilities Research Center grant P30 HD40677, and a National Down Syndrome Society grant to L.C.

\section{References}

1 Contestabile A, Fila T, Ceccarelli C, Bonasoni P, Bonapace L, Santini D, Bartesaghi R, Ciani E: Cell cycle alteration and decreased cell proliferation in the hippocampal dentate gyrus and in the neocortical germinal matrix of fetuses with Down syndrome and in Ts65Dn mice. Hippocampus 2007;17:665-678.

-2 Bernert G, Nemethova M, Herrera-Marschitz M, Cairns N, Lubec G: Decreased cyclin dependent kinase in brain of patients with Down syndrome. Neurosci Lett 1996; 216:68-70.

-3 Gardiner K, Fortna A, Bechtel L, Davisson MT: Mouse models of Down syndrome: how useful can they be? Comparison of the gene content of human chromosome 21 with orthologous mouse genomic regions. Gene 2003;318:137-147.
4 Kahlem P, Sultan M, Herwig R, Steinfath M, Balzereit D, Eppens B, Saran NG, Pletcher MT, South ST, Stetten G, Lehrach H, Reeves RH, Yaspo ML: Transcript level alterations reflect gene dosage effects across multiple tissues in a mouse model of Down syndrome. Genome Res 2004;14:1258-1267.

-5 Baxter LL, Moran TH, Richtsmeier JT, Troncoso J, Reeves RH: Discovery and genetic localization of Down syndrome cerebellar phenotypes using the Ts65Dn mouse. Hum Mol Genet 2000;9:195-202.

6 Insausti AM, Megias M, Crespo D, CruzOrive LM, Dierssen M, Vallina IF, Insausti R, Florez J: Hippocampal volume and neuronal number in Ts65Dn mice: a murine model of Down syndrome. Neurosci Lett 1998;253: 175-178.
7 Olson LE, Roper RJ, Baxter LL, Carlson EJ, Epstein CJ, Reeves RH: Down syndrome mouse models Ts65Dn, Ts1Cje, and Ms1Cje/ Ts65Dn exhibit variable severity of cerebellar phenotypes. Dev Dyn 2004;230:581589.

-8 Escorihuela RM, Fernandez-Teruel A, Vallina IF, Baamonde C, Lumbreras MA, Dierssen $\mathrm{M}$, Tobena A, Florez J: A behavioral assessment of Ts65Dn mice: a putative Down syndrome model. Neurosci Lett 1995;199: 143-146.

\9 Escorihuela RM, Vallina IF, Martinez-Cue C, Baamonde C, Dierssen M, Tobena A, Florez J, Fernandez-Teruel A: Impaired shortand long-term memory in Ts65Dn mice, a model for Down syndrome. Neurosci Lett 1998;247:171-174. 
10 Reeves RH, Irving NG, Moran TH, Wohn A, 23 Mahoney G, Perales F, Wiggers B, Herman B: Kitt C, Sisodia SS, Schmidt C, Bronson RT, Davisson MT: A mouse model for Down syndrome exhibits learning and behaviour deficits. Nat Genet 1995;11:177-184.

-11 Chakrabarti L, Galdzicki Z, Haydar TF: Defects in embryonic neurogenesis and initial synapse formation in the forebrain of the Ts65Dn mouse model of Down syndrome. J Neurosci 2007;27:11483-11495.

-12 Belichenko PV, Kleschevnikov AM, Masliah E, Wu C, Takimoto-Kimura R, Salehi A, Mobley WC: Excitatory-inhibitory relationship in the fascia dentata in the Ts65Dn mouse model of Down syndrome. J Comp Neurol 2009;512:453-466.

13 Belichenko PV, Masliah E, Kleschevnikov AM, Villar AJ, Epstein CJ, Salehi A, Mobley WC: Synaptic structural abnormalities in the Ts65Dn mouse model of Down syndrome. J Comp Neurol 2004;480:281-298.

- 14 Kleschevnikov AM, Belichenko PV, Villar AJ, Epstein CJ, Malenka RC, Mobley WC: Hippocampal long-term potentiation suppressed by increased inhibition in the Ts65Dn mouse, a genetic model of Down syndrome. J Neurosci 2004;24:8153-8160.

-15 Siarey RJ, Carlson EJ, Epstein CJ, Balbo A, Rapoport SI, Galdzicki Z: Increased synaptic depression in the Ts65Dn mouse, a model for mental retardation in Down syndrome. Neuropharmacology 1999;38:19171920.

16 Bianchi P, Ciani E, Contestabile A, Guidi S, Bartesaghi R: Lithium restores neurogenesis in the subventricular zone of the Ts65Dn mouse, a model for Down syndrome. Brain Pathol 2010;20:106-118.

17 Clark S, Schwalbe J, Stasko MR, Yarowsky PJ, Costa AC: Fluoxetine rescues deficient neurogenesis in hippocampus of the Ts65Dn mouse model for Down syndrome. Exp Neurol 2006;200:256-261.

18 Bianchi P, Ciani E, Guidi S, Trazzi S, Felice D, Grossi G, Fernandez M, Giuliani A, Calza L, Bartesaghi R: Early pharmacotherapy restores neurogenesis and cognitive performance in the Ts65Dn mouse model for Down syndrome. J Neurosci 2010;30:87698779.

19 Shearer MC, Bermingham SL: The ethics of paediatric anti-depressant use: erring on the side of caution. J Med Ethics 2008;34:710 714.

20 Grunfeld JP, Rossier BC: Lithium nephrotoxicity revisited. Nat Rev Nephrol 2009;5: 270-276.

21 Mahoney G, Wheeden CA, Perales F: Relationship of preschool special education outcomes to instructional practices and parentchild interaction. Res Dev Disabil 2004;25: 539-558.

22 Bonnier C: Evaluation of early stimulation programs for enhancing brain development. Acta Paediatr 2008;97:853-858. Responsive teaching: early intervention for children with Down syndrome and other disabilities. Downs Syndr Res Pract 2006;11: $18-28$.

24 Diamond MC, Krech D, Rosenzweig MR: The effects of an enriched environment on the histology of the rat cerebral cortex. J Comp Neurol 1964;123:111-120.

25 Rampon C, Tang YP, Goodhouse J, Shimizu E, Kyin M, Tsien JZ: Enrichment induces structural changes and recovery from nonspatial memory deficits in CA1 NMDAR1knockout mice. Nat Neurosci 2000;3:238244.

26 Rosenzweig MR, Krech D, Bennett EL, Diamond MC: Effects of environmental complexity and training on brain chemistry and anatomy: a replication and extension. J Comp Physiol Psychol 1962;55:429-437.

-27 Torasdotter M, Metsis M, Henriksson BG, Winblad B, Mohammed AH: Environmental enrichment results in higher levels of nerve growth factor mRNA in the rat visual cortex and hippocampus. Behav Brain Res 1998;93: 83-90.

28 Brown J, Cooper-Kuhn CM, Kempermann G, Van Praag H, Winkler J, Gage FH, Kuhn HG: Enriched environment and physical activity stimulate hippocampal but not olfactory bulb neurogenesis. Eur J Neurosci 2003; 17:2042-2046.

29 Llorens-Martin MV, Rueda N, MartinezCue C, Torres-Aleman I, Florez J, Trejo JL: Both increases in immature dentate neuron number and decreases of immobility time in the forced swim test occurred in parallel after environmental enrichment of mice. Neuroscience 2007;147:631-638.

30 Kempermann G, Kuhn HG, Gage FH: More hippocampal neurons in adult mice living in an enriched environment. Nature 1997;386: 493-495.

31 van Praag H, Christie BR, Sejnowski TJ, Gage FH: Running enhances neurogenesis, learning, and long-term potentiation in mice. Proc Natl Acad Sci USA 1999;96:

- 32 van Praag H, Kempermann G, Gage FH: Running increases cell proliferation and neurogenesis in the adult mouse dentate gyrus. Nat Neurosci 1999;2:266-270.

33 van Praag H, Schinder AF, Christie BR, Toni N, Palmer TD, Gage FH: Functional neurogenesis in the adult hippocampus. Nature 2002;415:1030-1034.

-34 Martinez-Cue C, Baamonde C, Lumbreras M, Paz J, Davisson MT, Schmidt C, Dierssen M, Florez J: Differential effects of environmental enrichment on behavior and learning of male and female Ts65Dn mice, a model for Down syndrome. Behav Brain Res 2002;134: 185-200. 13427-13431.
35 Martinez-Cue C, Rueda N, Garcia E, Davisson MT, Schmidt C, Florez J: Behavioral, cognitive and biochemical responses to different environmental conditions in male Ts65Dn mice, a model of down syndrome. Behav Brain Res 2005;163:174-185.

36 Allen DL, Harrison BC, Maass A, Bell ML, Byrnes WC, Leinwand LA: Cardiac and skeletal muscle adaptations to voluntary wheel running in the mouse. J Appl Physiol 2001; 90:1900-1908.

- 37 Konhilas JP, Widegren U, Allen DL, Paul AC Cleary A, Leinwand LA: Loaded wheel running and muscle adaptation in the mouse. Am J Physiol Heart Circ Physiol 2005; 289:H455-H465.

38 Tsai PP, Pachowsky U, Stelzer HD, Hackbarth H: Impact of environmental enrichment in mice. 1. Effect of housing conditions on body weight, organ weights and haematology in different strains. Lab Anim 2002; 36:411-419.

-39 Leal-Galicia P, Castaneda-Bueno M, QuirozBaez R, Arias C: Long-term exposure to environmental enrichment since youth prevents recognition memory decline and increases synaptic plasticity markers in aging. Neurobiol Learn Mem 2008;90:511-518.

40 Rose DS, Maddox PH, Brown DC: Which proliferation markers for routine immunohistology? A comparison of five antibodies. J Clin Pathol 1994;47:1010-1014.

41 Scholzen T, Gerdes J: The Ki-67 protein: from the known and the unknown. J Cell Physiol 2000;182:311-322.

42 Aguirre A, Gallo V: Postnatal neurogenesis and gliogenesis in the olfactory bulb from NG2-expressing progenitors of the subventricular zone. J Neurosci 2004;24:1053010541.

43 Hachem S, Aguirre A, Vives V, Marks A, Gallo V, Legraverend C: Spatial and temporal expression of $\mathrm{S} 100 \mathrm{~B}$ in cells of oligodendrocyte lineage. Glia 2005;51:81-97.

44 Llorens-Martin M, Torres-Aleman I, Trejo JL: Pronounced individual variation in the response to the stimulatory action of exercise on immature hippocampal neurons. Hippocampus 2006;16:480-490.

45 Llorens-Martin MV, Rueda N, Tejeda GS, Florez J, Trejo JL, Martinez-Cue C: Effects of voluntary physical exercise on adult hippocampal neurogenesis and behavior of Ts65Dn mice, a model of Down syndrome. Neuroscience 2010;171:1228-1240.

46 Mora F, Segovia G, del Arco A: Aging, plasticity and environmental enrichment: structural changes and neurotransmitter dynamics in several areas of the brain. Brain Res Rev 2007;55:78-88.

47 van Praag H, Kempermann G, Gage FH: Neural consequences of environmental enrichment. Nat Rev Neurosci 2000;1:191-198. 
48 Goshen I, Avital A, Kreisel T, Licht T, Segal M, Yirmiya R: Environmental enrichment restores memory functioning in mice with impaired IL-1 signaling via reinstatement of long-term potentiation and spine size enlargement. J Neurosci 2009;29:3395-3403.

- 49 Herring A, Ambree O, Tomm M, Habermann H, Sachser N, Paulus W, Keyvani K: Environmental enrichment enhances cellular plasticity in transgenic mice with $\mathrm{Al}$ zheimer-like pathology. Exp Neurol 2009; 216:184-192.

50 Komitova M, Perfilieva E, Mattsson B, Eriksson PS, Johansson BB: Enriched environment after focal cortical ischemia enhances the generation of astroglia and NG2 positive polydendrocytes in adult rat neocortex. Exp Neurol 2006;199:113-121.
1 Chakrabarti L, Best TK, Cramer NP, Carney RS, Isaac JT, Galdzicki Z, Haydar TF: Olig1 and olig2 triplication causes developmental brain defects in Down syndrome. Nat Neurosci 2010;13:927-934.

52 Kronenberg G, Reuter K, Steiner B, Brandt MD, Jessberger S, Yamaguchi M, Kempermann G: Subpopulations of proliferating cells of the adult hippocampus respond differently to physiologic neurogenic stimuli. J Comp Neurol 2003;467:455-463.

53 Mirochnic S, Wolf S, Staufenbiel M, Kempermann G: Age effects on the regulation of adult hippocampal neurogenesis by physical activity and environmental enrichment in the APP23 mouse model of Alzheimer disease. Hippocampus 2009;19:1008-1018.
4 Lee DW, Fernando G, Peterson RS, Allen TA, Schlinger BA: Estrogen mediation of injuryinduced cell birth in neuroproliferative regions of the adult zebra finch brain. Dev Neurobiol 2007;67:1107-1117.

55 Suzuki S, Gerhold LM, Bottner M, Rau SW, Dela Cruz C, Yang E, Zhu H, Yu J, Cashion $\mathrm{AB}$, Kindy MS, Merchenthaler I, Gage FH, Wise PM: Estradiol enhances neurogenesis following ischemic stroke through estrogen receptors alpha and beta. J Comp Neurol 2007;500:1064-1075.

56 Kim JY, Casaccia-Bonnefil P: Interplay of hormones and p53 in modulating gender dimorphism of subventricular zone cell number. J Neurosci Res 2009;87:3297-3305. 